\title{
A Nuclear Spin Selective Control over the DNA Repair Key Enzyme Might Renovate the Cancer-Fight Paradigm. DNA Polymerase Beta to Engage with a Magnetic Isotope Effect.
}

\author{
Oleg A. Shatalov ${ }^{1}$ Maxim E. Grigoryev², Alexander A. Bukhvostov³, \\ *Dmitry A. Kuznetsov²,4 \\ 1 - Russian Federal Research and Clinical Center for Pediatric Hematology, Oncology and Immunology, \\ Moscow 117997, Russia \\ 2 - N. I. Pirogov Russian National Research Medical University, Moscow 117997, Russia \\ 3 - I. M. Sechenov Moscow State Medical University, Moscow 124327, Russia \\ 4 - N. N. Semenov Institute for Chemical Physics of the Russian Academy of Sciences, Moscow 117997, \\ Russia \\ ${ }^{*}$ Corresponding Author: Dr. D. A. Kuznetsov, kuznano@mail.ru
}

\begin{abstract}
DNA Polymerase Beta (EC 2.7.7.7) is found to be operated by magnetic isotope effect (MIE) of Calcium once the $\mathrm{Mg}^{2+}$ ions replaced with the stable ${ }^{43} \mathrm{Ca}^{2+}$ isotopes inside the enzyme catalytic sites. The isotope mentioned is the only paramagnetic species of the Calcium isotopic set with a 0.135 natural abundance value and the negative 7/2 nuclear spin providing a nuclear magnetic moment equal to $1.317 \mathrm{Bohr}$ magnetons. As compared to the $\mathrm{Mg} /{ }^{40} \mathrm{Ca}$ substitution, a 2.25 -fold enzyme inhibition has been shown to provethe ${ }^{43} \mathrm{Ca}-\mathrm{MIE}$ dependent mode of the catalysis turning down.An ion-radical mechanism based on the singlet - triplet conversion of the enzyme generated intermediates (ion-radical pairs) is found to be engaged once the paramagnetic metal isotope involved into the catalysis studied.The MIE promotes a primary reaction in DNA synthesis constituting in electron transfer between the ion - radical forming partners, $\left[\mathrm{Ca}\left(\mathrm{H}_{2} \mathrm{O}\right)_{n}^{2+}\right]$ and $\left[\mathrm{Ca}^{2+}(\mathrm{dNTP})\right]$. Once the metal isotope substitution takes place inside just one of two DNA Polymerase Beta catalytic sites, a consequent ${ }^{43} \mathrm{Ca}$ - promoted inhibition leads to a residual synthesis of shorted DNA fragments that counts $25-35$ nucleotides in length contrasting with the $180 n-210 n$ DNA produced by either intact ${ }^{\circ}{ }^{40} \mathrm{Ca}$ - loaded polymerase. Being occurred simultaneously with a marked MIE - promoted enzyme inhibition, this fact itself makes possible to consider these short ("size-invalid") DNA segments hardly efficient in the DNA base - excision repair. The latter is a survival factor in leukemic cells where the DNApol $\beta$ was found overexpressed. That supports a standpoint considering theDNApol $\beta$ a legitimate target for antitumor agents since its inhibition deprives the malignant cell from a DNA base - excision repair in neoplasma. A possible trend making role of these data in the current developments on a novel concept - establishing chemical background for cancer therapies is in a focus.
\end{abstract}

\section{Indexing terms / Key words:}

magnetic isotope effect; nuclear spin selectivity; DNArepair; ${ }^{40} \mathrm{Ca}$ and ${ }^{43} \mathrm{Ca}$ isotopes; ion-radical path in the metal dependent enzymatic catalysis.

\section{Academic Discipline and Sub-Disciplines:}

Chemistry /Biochemistry

\section{SUBJECT CLASSIFICATION:}

Chemical Enzymology, Biophysical Chemistry, Metal Bio-Organic Catalysis, Bio-Organic Chemistry.

\section{TYPE (METHOD / APPROACH):}

Research Paper (Experimental Study).

\section{Council for Innovative Research}

Peer Review Research Publishing System

Journal: Journal of Advances in Chemistry

Vol. 4, No. 3

editor@cirworld.com

www.cirworld.com, member.cirworld.com 


\section{INTRODUCTION}

DNA Polymerase Beta (DNApoIB, EC 2.7.7.7) is a key player in the DNA base-excision repair (Sobol et al., 1996; Rechkunova\&Lavrik, 2010). Most of the variable DNApolB species werefound to be over - expressed in many malignant tumors (Shadan\& Villarreal, 1996; Kornberg \& Baker, 2005; Ljungmann, 2010; Bukhvostov et al, 2013). Moreover, this over - expression of DNApolB is highly linked to the survival of the human acute myeloblastleukosis (AML) cells and the poor prognosis of leukemic patients (Bergoglio et al, 2002; Albertella et al, 2005; Matsubara et al., 2007; Ljungmann, 2009; Carceres-Cortes, 2013).

Taking into account a known fact of the cell/tumor - specific structural diversity of the DNApolB superfamily (Beard \&Willson, 2006; Rechkunova\&Lavrik, 2010), some efforts were made to employ DNApolB inhibitors as the anti cancer agents (Matsubara et al, 20007; Ljungmann, 2009; Mizushina, 2009). In other words, enzymes of this group might be considered the legitimate targets for cytostatics as long as the latters are sufficient to meet such pharmacophore related requirements as the low toxicity, high selectivity and the efficiency of the enzyme inhibitory activity (Martin et al, 2010; Sanjeev et al, 2011).

One of the obstacles on a route of the DNApolB - targeting pharmacophores administration is their toxicity (Matsubara et al, 2007; Mizushina, 2009). Being $\mathrm{Mg}^{2+}$ - dependent matalloenzymes (two $\mathrm{Mg}^{2+}$ ions loosely coordinated inside two separate catalytic sites), DNApolB species were found to be controllable by a so called magnetic isotope effects (MIE) of the non - toxic bivalent metal ions, ${ }^{25} \mathrm{Mg}$, and ${ }^{67} \mathrm{Zn}$ (Buchachenko et al, 2013). This nuclear spin selective path of the enzyme activity regulation has been revealed for a number of metalloenzymes (Buchachenko, 2009; Buchachenko et al, 2010 - 2012). The mechanism beyond involves a singlet - triplet conversion of the ion - radical intermediates formed during the enzymatic intermolecular transfer of phosphate (Buchachenko, 2009; Buchachenko et al, 2012). As a result, these spin - possessing (magnetic) ions, ${ }^{25} \mathrm{Mg}^{2+}$ and ${ }^{67} \mathrm{Zn}^{2+}$, work as the far better suppressors for DNApolB reaction compared to the spinless (non - magnetic) ions of the very same metals (Buchachenko et al, 2013). Noteworthy, these inhibitorsare no doubt the non - toxic ones (Orlova et al, 2012).

Furthermore, the endo - osmotic inter - enzyme substitution of endogenous magnesium with other magnetic bivalent metal ions like ${ }^{43} \mathrm{Ca}^{2+}$ or ${ }^{67} \mathrm{Zn}^{2+}$ leads to an essential MIE expressed in several kinases directed phosphate transfer enzymatic reactions - in both pure enzyme tests and leukemia cell cultures (Buchachenko et al, 2011; 2012; Orlova et al, 2012). In a later case, some porphyrine - based amphililicnano - cationites were used to deliver the magnetic ions into the cell, regardless the ion concentration gradient vector (Amirshahi et al, 2008; Kuznetsov et al, 2010; Orlova et al, 2012).

It would be safe to say, therefore, that the MIE - promoting pharmacophores could engage the DNApolB molecular targets in anti - cancer therapies. This itself requires a firm biochemical, to be exact - chemico- enzymological, background.

Since the blasticleukemias, acute myeloblast ones (AML) including, are known for their DNApolB over - expression (Ljungmann, 2009, 2010; Bukhvostov et al, 2013; Carceres - Corties, 2013), it makes sense to investigate the MIE pharmacological potential using enzyme isolated from these peculiar cancer cells. Earlier, we have purified and detail characterized the unique tumor - specific DNApolB over - expressed in AML/HL-60 cells (Bukhvostov et al, 2013). In a present study, we're evaluating the ${ }^{43} \mathrm{Ca}-\mathrm{MIE}$ impact on this enzyme function with a special respect to further perspectives in anti - leukemia therapy pre - clinical developments.

\section{MATERIALS AND METHODS}

\section{Enzyme}

The enzyme samples, DNA Polemerase Beta (DNApolB, EC 2.7.7.7), were previously purified from the AML/HL-60 cell chromatin according to Bukhvostov et al, 2013.

\section{Labeled products}

${ }^{40} \mathrm{CaO}$ and ${ }^{43} \mathrm{CaO}$ species, A grade, $96.8 \%$ and $98.7 \%$ isotopic purity, respectively, were purchased from Gamma Lab AS (Spain). Tritium labeled DNA precursor, [Methyl-1,2- ${ }^{3} \mathrm{H}$ ]dTTP with a specific activity of $90-120 \mathrm{Ci} / \mathrm{mmol}$, NET520A, was purchased from New England Nuclear, Inc., USA.

\section{Reagents and disposal materials}

DNAse-free agarose (Helicon Co., UK); ethidium bromide (AppliChem AG, Sweden); single strand DNA markers kit, $30 n-550 n$ (SibEnzyme Ltd, Russia); AccuPrep Genomic DNA Extraction Kit (Bioneer Ltd, Korea); ethanol, acetone, $\mathrm{HCl}$, salts and buffers, all of $A$ grade, were purchased from Serva $\mathrm{GmbH}$ (Germany). 20CR fiberglass filters (Mollipore Co., France) and RX5 [3H]sensitive autoradiography films (Fuji Corp, Japan) were employed.

\section{Enzyme pre - incubation loading with exogenous $\mathrm{Ca}$ isotopes}

To convert ${ }^{40} \mathrm{CaO}$ and ${ }^{43} \mathrm{CaO}$ into chloride salts, a conventional acidic treatment has been performed first (Buchachenko et al, 2011). Once the isotopic-pure salt sample solution adjusted to a stock $1.0 \mathrm{M}$ concentration by the flame atomic absorption spectrophotometry (LQ600 AAA System, Shimadzu Corp, Japan), a routine incubation mixture has been composed as described by Buchachenko et al, 2013. This mixture was employed then to replace (endo - 
osmotic ion substitution, EOIS) the enzyme endogenous magnesium with an exogenous $\mathrm{Ca}^{2+}$ under the following conditions: $15 \mathrm{mMTris}-\mathrm{HCl}\left(\mathrm{pH}\right.$ 8.0) / $20 \mathrm{mM} \mathrm{CaCl}_{2} / 1.5 \mathrm{mM}$ EDTA / 60 - 80 microgram pure enzyme per $1.0 \mathrm{~mL} /$ $+37^{\circ} \mathrm{C}, 2$ hrs (Buchachenko et al, 2013). To monitor the enzyme - bound Calcium level values estimated in pg Ca per $1.0 \mathrm{mg}$ protein, the fiberglass filter retained acetone - precipitated pellets (acetone washed, $100 \mathrm{~mL} / \mathrm{cm}^{3}$ ) were analyzed by X-ray fluorescent spectrometry in SL420 XF Analytical System, Bruker GmbH, Germany (Buchachenko et al, 2011; Svistunov et al, 2013). For protein measurements, a Bradford - like routine colorimetric procedure has been applied (Katoch, 2011; Bukhvostov et al, 2013).

\section{DNApolB catalytic activity measurements}

To detect and quantify the enzymespecific catalytic activity, our original technique has been employed (Bukhvostov et al, 2013). The resulted activity values were expressed in amounts of the labeled DNA precursor incorporated into the enzyme - directed nascent single strand DNA sequences corrected to $1.0 \mathrm{mg}$ pure enzyme, i.e. $\left[{ }^{3} \mathrm{H}\right] \mathrm{cpmDNA} / \mathrm{mg}$ protein. 220LX Liquid Scintillation Counter (Wallac OY, Finland) employed. The protein ultramicroamounts were estimated according to Itzhaki\& Gill, 1964. The post - incubation mixtures were subjected to a quantitative extraction of the DNA ultramicroamounts using an AccuPrep Genomic DNA Extraction Kit (Bioneer, Korea) as described by Mikami et al, 2004, for further DNApolB activity and DNA size detection electrophoresis tests. In diluted solutions, the DNA ultramicroamount measurements were performed according to Bukhvostov et al, 2013.

\section{DNA electrophoresis}

A standard 1.7\% agarose gel electrophoretic technique has been employed (Reichman et al, 1957, modification: Bukhvostov et al, 2013). Prior to the samples supply, the routine colorimetric DNA measurements were performed (Burton, 1956). To observe an immediate result, the ethidium bromide treated unfixed gels were studied in the ImageQuant LAS4000 UV Scanner - Visualizer, GE HealthCare Life Sciences, Inc., USA (Bukhvostov et al, 2013). The gel $[3 \mathrm{H}]$ radioautographs were registered as described in Katoch, 2011.

\section{Statistics}

The experiment data repetition preciseness as well as a significance of the experiment / control data differences were elucidated by a non - parametric standard technique for $n$ lower than 6 (Brown \& Hollander, 2007). The data were processed in HP700E analytical module (Hewlett Packard, Inc., USA) using the VaryLab-6 software package (Litekh Ltd, Russia).

\section{RESULTS AND DISCUSSION}

In a number of previously conducted studies, a universal mode of the nuclear spin dependent effects (MIE) expressing in several metalloenzyme directed reactions was clearly proven and specified (Amirshahi et al, 2008; Buchachenko et al, 2009 - 2013; Kuznetsov et al, 2010; Orlova et al, 2012). Thus, the DFT-method provided simulation models show why magnetic and non - magnetic bivalent metal ions act differently once involved into the phosphate carrying enzymatic catalysis (Buchachenko et al, 2010, 2012, 2013). A wide diversity of the phosphate transferring metalloenzymes, including the HL-60 DNApolB, was found operable (controllable) by those above mentioned magnetic isotopes (Buchachenko et al, 2012, 2013) which makes a scheme presented in Figure 1 a quite legitimate way to interpret the ${ }^{43} \mathrm{Ca}-\mathrm{MIE} / \mathrm{DNApolB}$ interaction we're about to describe.

Being a self - sufficient kind of illustration, this scheme (Figure 1) deserves, nonetheless, a brief comment. The magnetic $\left({ }^{43} \mathrm{Ca}\right)$ nuclei induced singlet - triplet conversion of the ion - radical pair is a key element of this quantum mechanical mechanism (Buchachenko, 2009; Buchachenko et al, 2012). Consequently, this non - nucleophilic, very fast ion - radical reaction is to desynchronize the orchestrated work of two separate metal - possessing DNApolB catalytic sites. This, in turn, might deprive one of them of an appropriate functional interaction with a second one (Buchachenko et al, 2013). This statement is in accordance with the data on unequal ion accessibility of different catalytic sites in enzyme studied (Cowan, 2002; Kornberg \& Baker, 2005; Beard \&Willson, 2006; Rechkunova\&Lavrik, 2010).

However, there is one attention catching point in the ${ }^{43} \mathrm{Ca}-\mathrm{MIE}$ we observed which is a simultaneous (a) enzyme inhibition and (b) an essential decrease of a maximum size of the DNA fragments produced, from nearly $200 \mathrm{n}$ to about $30 n$ (Figures 2 and 3). A marked difference between the results obtained in ${ }^{40} \mathrm{Ca}$ (non - magnetic) and ${ }^{43} \mathrm{Ca}$ (magnetic) isotope tests is enough to exclude any doubt regarding the MIE nature of the phenomenon we've seen here (Buchachenko, 2009; Buchachenko et al, 2012).

Noteworthy, this is the first report ever on the MIE - promoted changes in lengths of DNA blocks processed by DNApolB, a target for magnetic ions. Fast UV - EtBr visualization of key results (Figure 2) was then completed with the detailed radiometric tests conducted in both DNA electrophoresis gel autioradiography and the enzyme catalytic activity measurements (Figure 3).

Taking into account that the DNApoIB synthesized DNA segment length was found to be one of the critical parameters for the DNApolB - directed DNA repair and, hence, to the cell survival (Sobol et al, 1996; Kornberg \& Baker, 2005; Beard \&Willson, 2006; Ljungmann, 2010; Rechkunova\&Lavril, 2010), we might assume a certain pharmacological potential beyond the data presented in Figures $1-3$. To our opinion, this assumption makes sense due to a known fact of the DNApolB over - expression occurred in most leukemic cells (Shadan\& Villarreal, 1996; Albertella et al, 2005; Matsubara et al, 2007; Martin et al, 2010) including the HL-60 ones (Bukhvostov et al, 2013). 
Looking at this biochemical data through the "pharmacology spectacles", we're facing two major problems, both related to the task of making the leukemic DNApolB a real molecular target for magnetic metal ions. First, the latters must be administered using a targeted delivery system of some sort. Second, the in situ intracellular ferromagnetic ions content ( $\mathrm{Fe}^{2+}$, first of all) must be considered as long as a target compartment (organella, cell, tissue) is known.

Concerning the targeted delivery of bivalent metal ions, some low toxic nano - cationites were qualified as the efficient $\mathrm{Me}^{2+}$ - carriers in both in vitro and in vivo studies. Thus, ${ }^{25} \mathrm{Mg}^{2+}$ ions were selectively delivered towards myocardiocytes and lymphocytes in rats owing to nano - cationites based on water - soluble porphyrine adducts of fullerene- $\mathrm{C}_{60}$; the porphyrine - affine signaling mitochondria membrane proteins were playing a role of traps catching and then retaining these pharmacophores (Amirshahi et al, 2008; Kuznetsov et al, 2010; Orlova et al, 2013 a, b). Several oligoheterocyclicaminothiolateswere also found efficient to provide the cell plasmatic membranesl and nuclei permeability for $\mathrm{Ca}^{2+}, \mathrm{Mn}^{2+}, \mathrm{Cu}^{2+}$ and $\mathrm{Zn}^{2+}$ ions in leukemic cells in vitro (Shimanovsky et al, 2010). All these and related medicinal nano - particles are to release the cations they're loaded with in response to a slight metabolic acidosis, so common for the most malignant tumors known (Amirshahi et al, 2008; Kuznetsov et al, 2010; Shimanovsky et al, 2010; Orlova et al, 2013 b).

In our previous studies, we have revealed that MIE are hardly inducible in iron - rich mammalian tissues (spleen, liver) as compared to the iron -poor ones (Shatalov et al, 2012; Svistunov et al, 2013). Obviously, these were the easily predictable results. There is no way for ${ }^{43} \mathrm{Ca}-\mathrm{MIE}$ to get expressed in a "heavily iron - polluted" environment (Buchachenko et al, 2012). That's why it is important to find out a general regularity of such a dependence as this: MIE $=f\left(\left[\mathrm{Ca}^{2+}\right]\right)$. This is what our findings (Figure 4) are all about. The regularity shown here is worthy of being used to correct pharmacodynamics patterns in further ${ }^{43} \mathrm{Ca}-\mathrm{MIE}$ studies.

A non - Markoff population dynamics model allows to predict a cytostatic efficiency for ${ }^{43} \mathrm{Ca}^{2+}$ - loaded PMC16 nano particles (porphyrylcyclohexylfullerene), cation releasing pharmacophore (Kuznetsov et al, 2010). Such cytostatic effect was observed by Orlova et al (2012) in experiments with [ $\left.{ }^{67} \mathrm{Zn}\right]_{4} \mathrm{PMC} 16$ carriers in normal lymphocytes and human leukemia cell lines.

To summarize the results presented in Figures $1-4$, we may propose a biochemical path for the DNApolB engaging MIE of ${ }^{43} \mathrm{Ca}$. As a matter of fact, this scheme (Figure 5) is based on the ion - radical concept of the phosphate transferring metalloenzyme function which involves a numerous DFT - calculations and experimental data (Buchachenko et al, 2010 - 2013; Orlova et al, 2012, 2013 a, b; Shatalov et al, 2012; Svistunov et al, 2013). As seen from this chart, the only path for the dNTP-oxyradical decay in ${ }^{43} \mathrm{Ca}^{2+}$ - possessing DNApolB is a fast and irreversible ion - radical move leading to the nascent DNA chain growth (compare Figures 1 and 5).

Considering that one of the $\mathrm{Mg}^{2+}$ ions belonging to bicationicDNApolB molecule is hardly accessible to the endo osmotic isotope substitution, i. e. to the enzyme intermolecular metal ion replacement procedure (Sobol et al, 1996; Cowan, 2002; Kornberg \& Baker, 2005; Beard \&Willson, 2006; Rechkunova\&Lavrik, 2010), it would be reasonable to expect a maximum $\mathrm{Ca}^{2+}$ - enzyme incorporation level to be close to $50 \%$.

As we have confirmed (Figures 6 and 7), about a half of endogenous enzyme - bound magnesium was indeed replaced with calcium in our experiments. Keeping the intra-enzyme metal substitution conditions optimal (see Materials and Methods), we realized that not more than $54-58 \%$ of the protein - bound magnesium was in fact replaced with ${ }^{43} \mathrm{Ca}^{2+}$ (Figure 6). Two hour long incubation time scale was found optimal to reach the ion exchange (replacement) equilibrium point in $20 \mathrm{mM} \mathrm{CaCl}_{2}$ media (Figure 7). Most likely, the ${ }^{43} \mathrm{Ca}-\mathrm{MIE}$ we observed had indeed caused by dis-synchronization of functioning of two metal - containing enzyme catalytic sites which is a consequence of the insertion of magnetic ${ }^{43} \mathrm{Ca}^{2+}$ into just one - the only accessible one - of the above mentioned two metal possessing domains.

Last not least, DNApoIB makes a contribution to the cell chromatin stability/flexibility transitions. Being located in both deep and superficial strata of chromatin (Bergoglio et al, 2002; Matsubara et al, 2007; Ljungmann, 2009, 2010; Martin et al, 2010; Shimanovsky et al, 2010), this enzyme fits the requirements we have for a molecular target accessibility for magnetic metal ions delivered by an appropriate ion - releasing pharmacophore.

\section{CONCLUSION}

The $\mathrm{Ca}$ - Mg substitution occurred inside the AML/HL-60 chromatin DNApolB catalytic sites leads to a sharp inhibition of this enzyme once the magnetic ${ }^{43} \mathrm{Ca}$ isotope got engaged. This phenomenon had caused by the ${ }^{43} \mathrm{Ca}-\mathrm{related}$ magnetic isotope effect known for its ion - radical mechanism specified earlier by Buchachenko et al (2009 - 2013). Moreover, the ${ }^{43} \mathrm{Ca}-\mathrm{MIE}$ manifests itself not only in the DNApoIB inhibition but in a residual synthesis of abnormally short, DNA-repair hardly sufficient, "invalid" DNA fragments. Since the isotope substitution performed was efficiently managed in the simple endo - osmotic pressure tests, the data presented are worthy of further study on their pharmacological potential. This potential derives also from the DNApolB properties making it a promising candidate to a role of the molecular target for ${ }^{43} \mathrm{Ca}^{2+}$ - inhibitor in pre-clinical safe cytostatics developments. 


\section{REFERENCES}

Albertella S., Lau A., O'Connor M.J. (2005) The overexpression of specialized DNA polymerases in cancer. DNA Repair, 4: 583 - 593.

Amirshahi N., Alyautdin R.N., Sarkar S., Rezayat S.M., Orlova M.A., Trushkov I.V., Buchachenko A.L., Kuznetsov D.A. (2008) New porphyrin adduct of fullerene- $\mathrm{C}_{60}$ : a promising nanotool for medicinal use in the heart muscle hypoxia cases. International Journal of NanoScience, 7: 113 - 135.

Beard W.A. \&Willson S.H. (2006) Structure and mechanism of DNA polymerase beta. Chemical Reviews, $106: 361$ 382.

Bergoglio V., Pillare M.J., Lacroix-Triki M. (2002) Deregulated DNA polymerase beta induced chromosome instability tumorigenesis. Cancer Research, 62: 3511 - 3514.

Brown B.W.M. \& Hollander M. (2007) Statistics. A Biomedical Introduction.Wiley - Blackwell: Weinheim.

Buchachenko A.L. (2009) Magnetic Isotope Effect in Chemistry and Biochemistry. Nova Science Publishers: New York.

Buchachenko A.L., Kuznetsov D.A., Breslavskaya N.N. (2010) lon - radical mechanism of enzyme ATP synthesis: DFT calculations and experimental control. Journal of Physical Chemistry series B, 114: 2287 - 2292.

Buchachenko A.L., Kuznetsov D.A., Breslavskaya N.N., Shcheglova L.N., Arkhangelsky S.E. (2011) Calcium induced ATP synthesis: isotope effect, magnetic parameters and mechanism. Chemical Physics Letters, 505: 130 - 134.

Buchachenko A.L., Kuznetsov D.A., Breslavskaya N.N. (2012) Chemistry of enzymatic ATP synthesis: an insight through the isotope window. Chemical Reviews, 112: $2042-2058$.

Buchachenko A.L., Orlov A.P., Kuznetsov D.A., Breslavskaya N.N. (2013) Magnetic isotope and magnetic field effects on the DNA synthesis. Nucleic Acids Research, DOI:10.1093/nar/gkt537.

Bukhvostov A.A., Shatalov O.A., Orlov A.P., Kuznetsov D.A. (2013) An atypical DNA polymerase beta overexpressed in human AML/HL-60 malignant cells. Journal of Cancer Science and Therapy, 5: 94 - 99.

Burton K. (1956) Diphenylamine colorimetric method for DNA measurements. Biochemical Journal, 62 : 315 - 318.

Caceres-Cortes J.R. (2013) Blasticleukaemias (AML): a biologist's view. Cell Biochemistry and Biophysics, 66: 13 22.

Cowan J.A. (2002) Structural and catalytic chemistry of magnesium - dependent enzymes. BioMetals, 15: 225 - 235.

Itzhaki R.F. \& Gill D.M. (1964) Microbiurete technique for protein measurements. Analytical Biochemistry, 4: 401 - 407.

Katoch R. (2011) Analytical Techniques in Biochemistry and Molecular Biology. Springer: Heidelberg - New York.

Kornberg A. \& Baker T.A. (2005) DNA Replication. $2^{\text {nd }}$ Edition, Nucleic Acids Science Books: New York.

Kuznetsov D.A., Roumiantsev S.A., Fallahi M., Amirshahi N., Makarov A.V., Kardashova K.S. (2010) A non - Markoff population dynamics: does it help to optimize the chemotherapeutic strategy ? International Journal of Biomedical Sciences, 6: $100-106$.

Ljungmann M. (2009) Targeting in the DNA damage response in cancer. Chemical Reviews, 109: 2929 - 2936.

Ljungmann M. (2010) The DNA damage response - repair or despair ?Environmental and Molecular Mutagenesis, 51: $879-889$.

Martin S., McCabe N., Mullarkey M., Gummins R., Burgess D.J., Nakabeppu Y., Oka S., Kay E., Lord C., Ashworth A. (2010) DNA polymerases as potential therapeutic targets in cancers. Cancer Cell, 17: 235 - 248.

Matsubara K., Saito A., Tanaka A., Nakajima N., Akagi R., Mori M., Mizushina Y. (2007) DNA polymerases in carcinogenesis. Life Sciences, 80: 1578 - 1585.

Mikami T., Satoh N., Hatayama I., Nakane A. (2004) The inhibition effect of buthioninesulfoximine on cytopathic effect and apoptosis induced by human echovirus 9. Archives of Virology, 149: $1117-1128$.

Mizushina Y. (2009) Specific inhibitors of Mammalian DNA polymerase species. Biosciences, Biotechnology and Biochemistry, 73: 1239 - 1251.

Orlova M.A., Osipova E.Y., Roumiantsev S.A. (2012) Effect of ${ }^{67}$ Zn-nanoparticles on leukemic cells and normal lymphocytes. British Journal of Medicine and Medical Research, 2: 21 - 30.

Orlova M.A., Trofimova T.P., Orlov A.P., Shatalov O.A. (2013 a) Fullerene derivatives: a new type of pharmacophores suitable for apoptosis control. British Journal of Medicine and Medical Research, 3: 1721 - 1737.

Orlova M.A., Trofimova T.P.,Shatalov O.A. (2013 b) Fullerene nanoparticles operating the apoptosis and cell proliferation processes in normal and malignant cells. Der Pharmacia Lettre, 5: 99 - 139. 
Rechkunova N.I. \&Lavrik O.I. (2010) Nucleotide excision DNA repair in higher eukaryotes. Subcellular Biochemistry, 50: $251-277$.

Reichman M.E., Rice S.A., Thomask C.A., Doty P. (1957) Further examination of the molecular weight of deoxyribonucleic acid. Journal of the American Chemical Society, 76: $3047-3053$.

Shadan F.F. \& Villarreal L.P. (1996) Potential role of DNA polymerase beta in gene therapy against cancer: a case of colorectal cancer. Medicinal Hypotheses, 47: $1-9$.

Shatalov O.A., Svistunov A.A., Napolov Y.K., Bukhvostov A.A., Kuznetsov D.A., Alyautdin R.N. (2012) The tissue specific "ferromagnetic attack" on hyperactivation of ATP synthesis by magnesium-25 in mitochondria. Magnesium Research, 25: 177 - 181.

Shimanovsky N.L., Epinetov M.A., Melnikov M.Y. (2010) Molecular and Nano - Pharmacology. Physmathlit Press: Moscow (in Russian).

Sobol R.W., Horton J.K., Kohn R., Gu H., Singhal R.K., Prasad R., Rajewsky K., Wilson S.H. (1996) Requirement of mammalian DNA polymerase - beta in base - excision repair. Nature, 379: 183 - 186.

Svistunov A.A., Napolov Y.K., Bukhvostov A.A., Shatalov O.A., Alyautdin R.N., Kuznetsov D.A. (2013) The mitochondria free iron content to limit an isotope effect of ${ }^{25} \mathrm{Mg}^{2+}$ in ATP synthesis: A caution. Cell Biochemistry and Biophysics, 66: $417-419$.

\section{A SET OF SEVEN FULL - MARKED FIGURES IS ENCLOSED AS THE ATTACHED FILES}

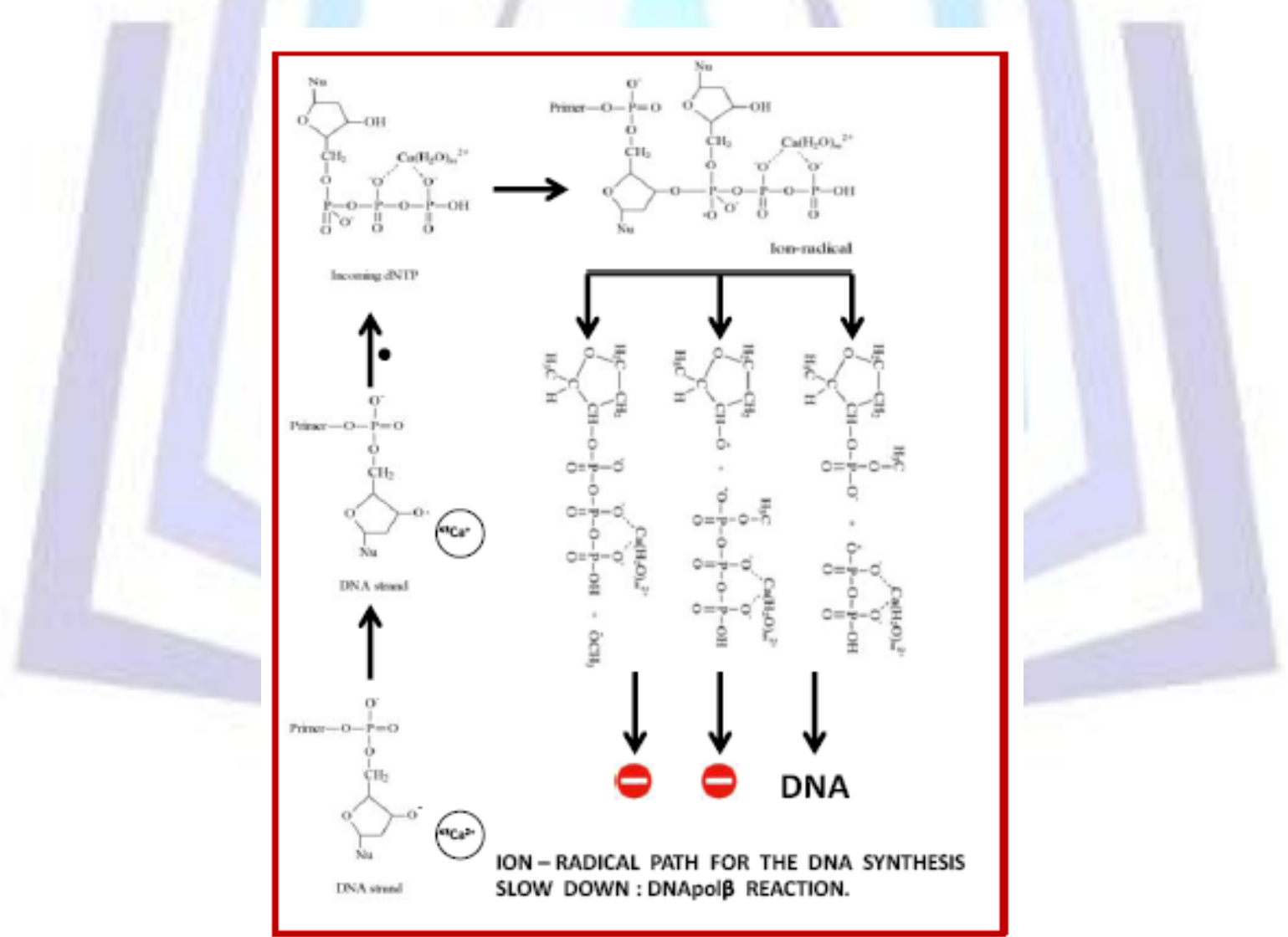

Figure 1.

ION - RADICAL PATH FOR THE DNA SYNTHESIS SLOW DOWN :DNApoIß REACTION. 


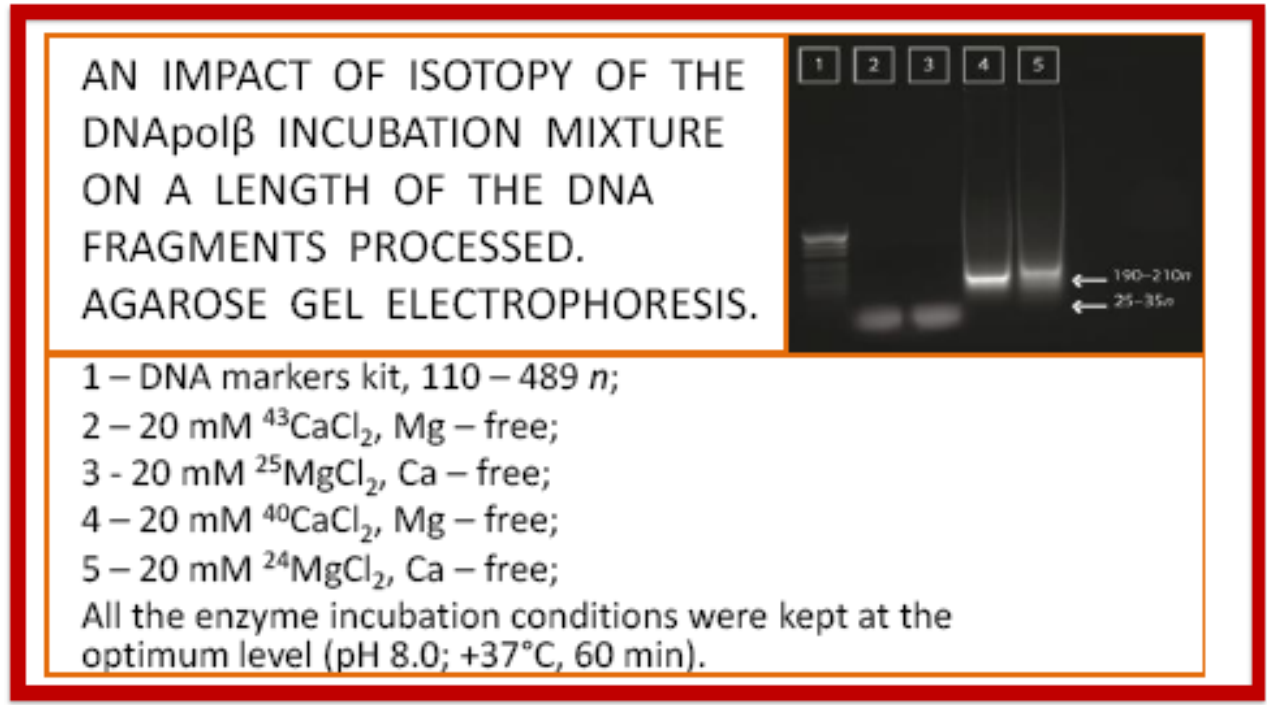

Figure 2.

AN IMPACT OF ISOTOPY OF THE DNAPOI $\beta$ INCUBATION MIXTURE ON A LENGTH OF THE DNA FRAGMENTS PROCESSED. AGAROSE GEL ELECTROPHORESIS.

1 - DNA markers kit, 110 - 489 ; 2 - $20 \mathrm{mM} 43 \mathrm{CaCl}, \mathrm{Mg}$ - free; 3 - $20 \mathrm{mM}$ 25MgCl2, Ca - free; 4 - $20 \mathrm{mM} \mathrm{40CaCl}$, $\mathrm{Mg}$ - free; 5- $20 \mathrm{mM} 24 \mathrm{MgCl} 2, \mathrm{Ca}$ - free;

All the enzyme incubation conditions were kept at the optimum level $\left(\mathrm{pH} 8.0 ;+37^{\circ} \mathrm{C}, 60 \mathrm{~min}\right)$.
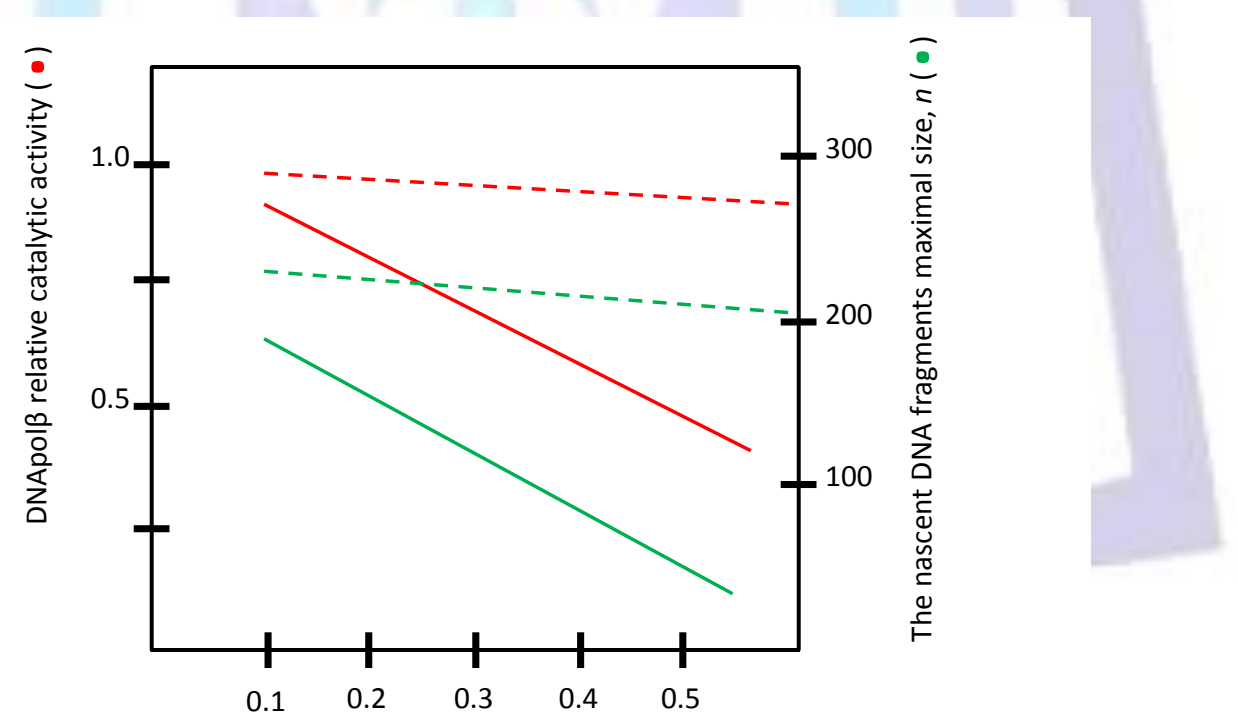

Fraction of Calcium in the enzyme - bound bivalent metal pool

${ }^{43}$ Ca-MIE in DNApolß FUNCTION

Controls: ${ }^{40} \mathrm{Ca} / \mathrm{Mg}$ substitution (---/---);

Experiment: ${ }^{43} \mathrm{Ca} / \mathrm{Mg}$ substitutio $(\bullet / \bullet)$.

Figure 3.

FRACTION OF CALCIUM IN THE ENZYME - BOUND BIVALENT METAL POOL 


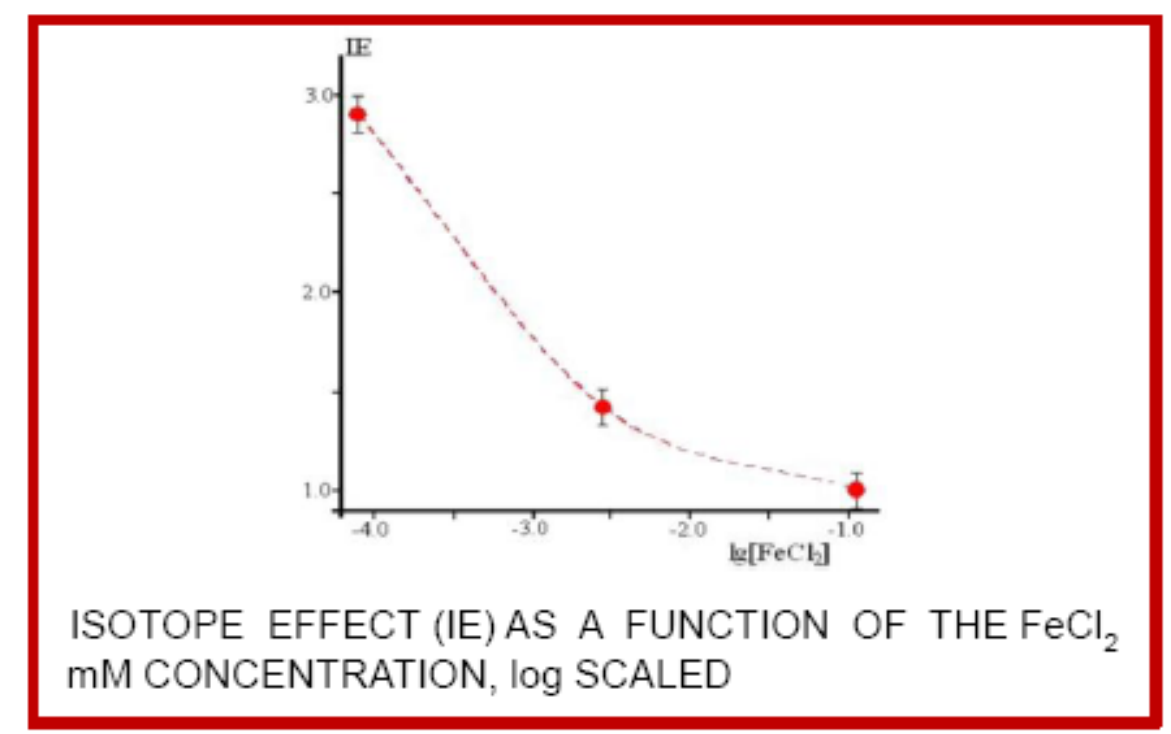

Figure 4.

ISOTOPE EFFECT (IE) AS A FUNCTION OF THE FeCI2 mM CONCENTRATION, Iog SCALED

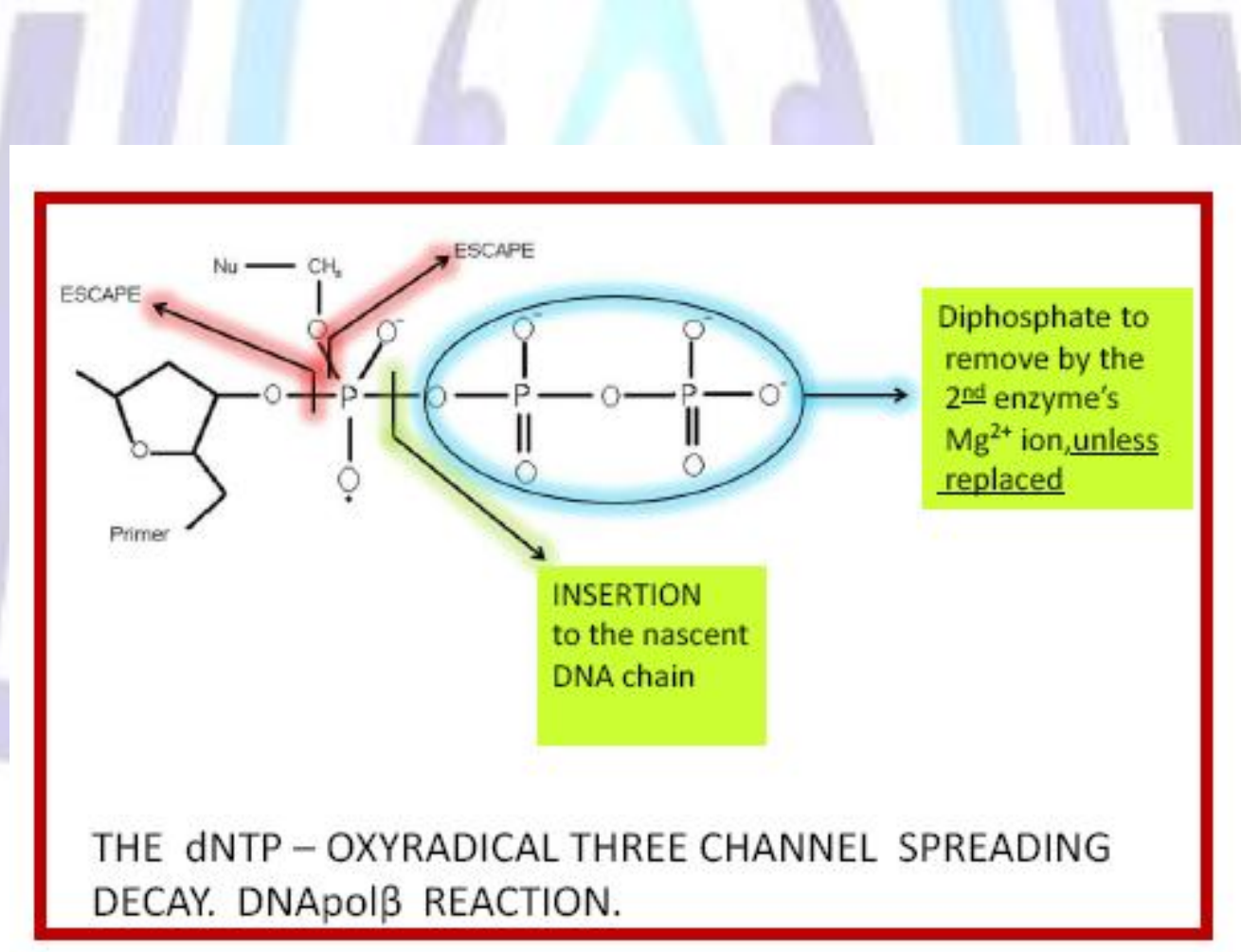

Figure 5.

THE dNTP - OXYRADICAL THREE CHANNEL SPREADING DECAY.DNApoIß REACTION. 


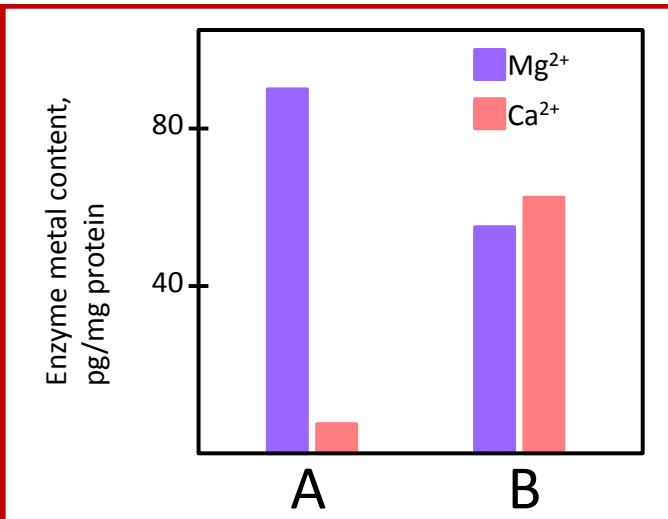

THE HIGHEST - REACHABLE LEVELS OF SUBSTITUTION OF ENDOGENOUS

$\mathrm{Mg}^{2+}$ WITH CALCIUM IN PURIFIED HL60 DNAPOIß (20 mMCaCL $2 / 15 \mathrm{mM}$ Tris- $\mathrm{HCl}(\mathrm{pH} 8.0) / 1.5 \mathrm{mM}$ $\left.\mathrm{EDTA} /+37^{\circ} \mathrm{C} / 2 \mathrm{hrs}\right)$.

A - Control (intact enzyme);

B - Experiment (Mg - Ca substitution).

Figure 6.

THE HIGHEST - REACHABLE LEVELS OF SUBSTITUTION OF ENDOGENOUS Mg2+ WITH CALCIUM IN PURIFIED HL60 DNApolß (20 mMCaCL2/15 mMTris- $\left.\mathrm{HCl}(\mathrm{pH} 8.0) / 1.5 \mathrm{mM} \mathrm{EDTA} /+37^{\circ} \mathrm{C} / 2 \mathrm{hrs}\right)$.

A - Control (intact enzyme); B - Experiment (Mg - Ca substitution).

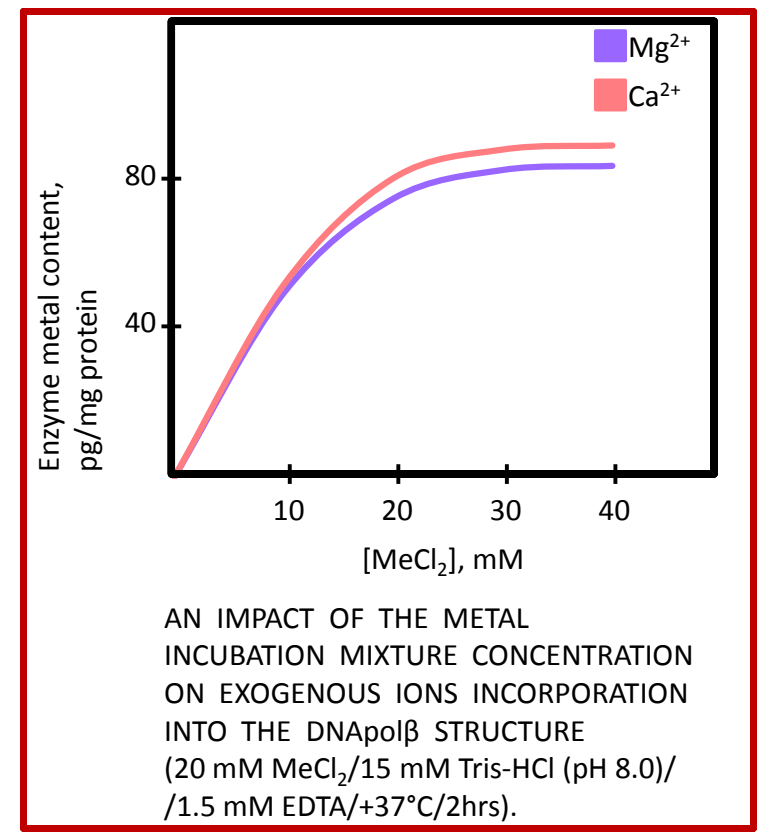

Figure 7.

AN IMPACT OF THE METAL INCUBATION MIXTURE CONCENTRATION ON EXOGENOUS IONS INCORPORATION INTO THE DNAPOIß STRUCTURE $(20 \mathrm{mM} \mathrm{MeCl} 2 / 15 \mathrm{mMTris}-\mathrm{HCl}(\mathrm{pH} 8.0) / / 1.5 \mathrm{mM}$ $\left.\mathrm{EDTA} /+37^{\circ} \mathrm{C} / 2 \mathrm{hrs}\right)$. 